\title{
The Protein Kinase A Regulatory Subunit R1A (Prkarla) Plays Critical Roles in Peripheral Nerve Development
}

\author{
Li Guo, ${ }^{1}$ Audrey A. Lee, ${ }^{2}$ Tilat A. Rizvi, Nancy Ratner, ${ }^{1}$ and Lawrence S. Kirschner ${ }^{2,3}$ \\ ${ }^{1}$ Division of Experimental Hematology and Cancer Biology, Department of Pediatrics, Cincinnati Children's Hospital Medical Center, Cincinnati, Ohio \\ 45229, ${ }^{2}$ Department of Molecular, Virology, Immunology, and Medical Genetics, and ${ }^{3}$ Division of Endocrinology, Diabetes, and Metabolism, Department of \\ Internal Medicine The Ohio State University, Columbus, Ohio 43210
}

Signaling through cAMP has been implicated in Schwann cell (SC) proliferation and myelination, but the signaling pathway components downstream of cAMP required for SC function remain unknown. Protein kinase A (PKA) is a potential downstream effector of cAMP. Here, we induced loss of Prkarla, the gene encoding the type 1A regulatory subunit of PKA, in SC to study its role in nerve development; loss of Prkarla is predicted to elevate PKA activity. Conditional Prkarla knock-out in mouse SC (Prkarla-SCKO) resulted in a dramatic and persistent axonal sorting defect, and unexpectedly decreased SC proliferation in Prkarla-SCKO nerves in vivo. Effects were cell autonomous as they were recapitulated in vitro in Prkar1a-SCKO SC, which showed elevated PKA activity. In the few SCs sorted into 1:1 relationships with axons in vivo, SC myelination was premature in Prkarla-SCKO nerves, correlating with global increase in the cAMPregulated transcription factor 0ct-6 and expression of myelin basic protein. These data reveal a previously unknown role of PKA in axon sorting, an unexpected inhibitory role of PKA on SC cell proliferation in vivo and define the importance of Prkarla in peripheral nerve development.

\section{Introduction}

Schwann cells (SCs) are glial cells of the peripheral nervous system (PNS). During development, mouse neural crest cells differentiate into SC precursors (SCPs) at embryonic day (E) 12-13, and into immature SCs at E15-16 (Jessen and Mirsky, 1997; Woodhoo and Sommer, 2008). Immature SCs segregate progressively smaller groups of axons by extending processes into axon bundles in a process called radial sorting. SCPs and immature SCs proliferate rapidly, with the postnatal onset of myelination by SCs associating with single large diameter axons correlating with cellcycle exit (Stewart et al., 1993; Jessen and Mirsky, 2005). The transcription factors Krox-20, Oct-6 (SCIP or Pou3f1), and nuclear factor $\kappa \mathrm{B}(\mathrm{NF}-\kappa \mathrm{B})$ are crucial for SC proliferation and myelination (Pereira et al., 2012).

cAMP has been implicated as an important second messenger regulating SC proliferation and myelination (Jessen and Mirsky, 1991; Morgan et al., 1991). In vitro, cAMP enhances mitogendependent SC proliferation (Davis and Stroobant, 1990; Stewart et al., 1991; Jung-Testas et al., 1993; Kim et al., 1997; Monje et al., 2006). In rat SCs, high cAMP increases expression of myelin genes (Sobue et al., 1986). In mouse SCs, increasing levels of cAMP switches neuregulin 1 (NRG1) from a proliferative signal

\footnotetext{
Received Feb. 19, 2013; revised June 5, 2013; accepted June 8, 2013.

Author contributions: L.G., N.R., and L.S.K. designed research; L.G. and A.A.L. performed research; T.R. contributed unpublished reagents/analytic tools; L.G. analyzed data; L.G., N.R., and L.S.K. wrote the paper.

This study was supported by Grant NIH-R01 CA118032 (to N.R.) and the Department of Defense (DOD) Neurofi-

bromatosis Program (to L.S.K.). We thank Georgianne Ciraolo for assistance with electron microscopy.

The authors declare no competing financial interests.

Correspondence should be addressed to Dr Nancy Ratner, Cincinnati Children's Hospital Medical Center, 3333

Burnet Avenue, ML 7013, Cincinnati, 0H 45229. E-mail: nancy.ratner@cchmc.org.

DOI:10.1523/JNEUROSCI.0766-13.2013

Copyright $\odot 2013$ the authors $\quad 0270-6474 / 13 / 3317967-09 \$ 15.00 / 0$
}

to a myelin differentiation signal (Arthur-Farraj et al., 2011). Furthermore, in vivo Gpr126 is essential to initiate SC myelination through cAMP (Monk et al., 2009, 2011), and low cAMP levels in Rac1 mutant SCs result in the absence of SC myelin sheaths in vivo (Guo et al., 2012).

The best known downstream effector of cAMP is PKA. PKAmediated phosphorylation of the NF- $\kappa \mathrm{B}$ p 65 subunit is required for myelination in SC-neuron cocultures and a peak of PKA activity in the sciatic nerve occurs around the onset of myelination (Yoon et al., 2008). PKA is composed of two regulatory ( $\mathrm{RI} \alpha$ - or $\mathrm{RI} \beta$-, $\mathrm{RII} \alpha$ - or RII $\beta$-) and two catalytic subunits (Skalhegg and Tasken, 2000; Taylor et al., 2005). cAMP binding to regulatory subunits results in release of catalytic subunits, which then phosphorylate PKA substrates (Barradeau et al., 2002). Loss of regulatory subunits is predicted to increase PKA activity (Amieux et al., 2002; Cheng et al., 2008), and this was demonstrated in vivo and in vitro (Kirschner, 2009). Prkarla encodes the PKA regulatory subunit type IA (RI $\alpha$ ), an important effector of cAMP signaling in most cells and Prkarla gene is mutated in Carney Complex, a schwannoma predisposition syndrome (Bossis and Stratakis, 2004).

Despite significant in vitro data supporting the importance of cAMP in promoting SC proliferation and myelination, effects of PKA signaling on peripheral nerve have not been analyzed in vivo and relevant PKA subunits have not been defined. We induced Prkarla loss at the SCP stage of development, resulting in a dramatic and persistent axonal sorting defect, and decreased SC proliferation in Prkarla-SCKO nerves. In Prkarla null SCs sorted into 1:1 relationships with axons in vivo, myelination began prematurely, correlating with an increase in a cAMP-regulated transcription factor, SCIP/Oct-6, expression and increased myelin basic protein (MBP) expression. 


\section{Materials and Methods}

Generation of DhhCre directed conditional Prkarla knock-out mice. Prkarla flox/flox (Kirschner et al., 2005) mice were bred to DhhCre mice (Jaegle et al., 2003; Wu et al., 2008) to obtain DhhCre+; Prkarla flox/flox (Prkarla-SCKO) mice. Littermate DhhCre+; Prkarla flox/+ mice were used as controls. A lox-STOP-lox RFP allele (lslRFP) was used as a Cre recombination reporter (Madisen et al., 2010). The genotypes of Dhh and Prkarla alleles for all of the mice in our experiments were analyzed by PCR. The primers for DhhCre genotyping were 5'-GCGGTCTGGCAG TAAAAACTATC-3' (forward) and 5' -GTGAAACAGCATTGCTGTCAC TT-3' (reverse). The primers for Prkarla genotyping were 5'-GCAGGC GAGCTATTAGTTTA-3' (forward) and 5'-CATCCATCTCCTATCCCC TTT-3' (reverse). Primer 5'-CAAGCTAGCTTGGCTGGACGTA-3' (forward) was used to identify the Prkarla knock-out band. All mouse crosses were performed in a mixed genetic background, consisting primarily of the $F V B, C 57 \mathrm{Bl} / 6$, and 129 strains. All animal experiments were conducted in mice of both sexes.

Electron microscopy. Mice were anesthetized and fixed with electron microscopy fixation solution (3\% paraformaldehyde and 3\% glutaraldehyde in PBS, pH 7.4-7.6). Sciatic nerves of wild-type and mutant mice were dissected, postfixed, osmicated, embedded, and sectioned. The photographs of toluidine blue stained semithin sections $(1 \mu \mathrm{M})$ were taken by bright-field microscopy. High-magnification pictures of ultrathin sections stained with uranyl acetate and lead citrate were taken using a Hitachi H-7600 transmission electron microscope.

Western blots. Sciatic nerve tissue was homogenized using a TissueRuptor (Qiagen) or cultured cells were lysed in ice-cold lysis buffer (20 $\mathrm{mm} \mathrm{NaPO}_{4}$, $150 \mathrm{~mm} \mathrm{NaCl}, 2$ mм MgCl2, 0.1\% Nonidet P-40, 10\% glycerol, $10 \mathrm{~mm}$ sodium fluoride, $0.1 \mathrm{~mm}$ sodium orthovanadate, $10 \mathrm{~mm}$ sodium pyrophosphate, $10 \mathrm{~nm}$ okadaic acid, $1 \mathrm{~mm}$ dithiothreitol, $10 \mu \mathrm{g} / \mathrm{ml} \mathrm{leupeptin,} 10 \mu \mathrm{g} / \mathrm{ml}$ aprotinin, $10 \mu \mathrm{g} / \mathrm{ml}$ pepstatin, $10 \mu \mathrm{g} / \mathrm{ml}$ tosyl-L-phenylalanine chloromethyl ketone, and $10 \mu \mathrm{g} / \mathrm{ml} \mathrm{N} \alpha$-tosyl-L-lysine chloromethyl ketone). Homogenates were centrifuged at $6000 \times g$ for $10 \mathrm{~min}$ and protein extract supernatants were collected. Protein concentration was measured on a spectrophotometer using a Bio-Rad DC Protein Assay Kit. Equal amounts of protein were fractionated by $4-20 \%$ SDS-PAGE (NuStep) and transferred to PVDF membrane. Membranes were incubated with primary antibodies followed by appropriate secondary antibodies, and developed by GE Healthcare ECL Detection Reagents. The following primary antibodies were used: Prkarla (Cell Signaling Technology, 1:1000), ErbB3 (Santa Cruz Biotechnology, 1:500), P-AKT (Cell Signaling Technology, 1:1000), Akt (Cell Signaling Technology, 1:1000), P-Erk1/2 (Cell Signaling Technology, 1:1000), Erk1/2 (Cell Signaling Technology, 1:1000), Krox20 (Abcam, 1:500), Pmp22 (Abcam, 1:10,000), MBP (Calbiochem, 1:1000)c and $\beta$-actin (Cell Signaling Technology, 1:10,000). Anti-rabbit and anti-mouse HRP-conjugated secondary antibodies (1:5000) were purchased from Bio-Rad.

Immunohistochemistry. Sciatic nerves were dissected and fixed in $4 \%$ paraformaldehyde (PFA) overnight. For cryostat sections, fixed sciatic nerves were incubated in $20 \%$ sucrose buffer and then frozen in OCT compound (Sakura). Frozen blocks were cut into $6-8 \mu \mathrm{m}$ frozen sections using a Leica Cryostat. For paraffin sections, fixed sciatic nerves were incubated in $70 \%$ ethanol then processed in paraffin wax. Paraffin blocks were cut into $4 \mu \mathrm{m}$ paraffin sections. For staining, paraffin sections were deparaffinized and rehydrated before staining. Sodium citrate buffer ( $\mathrm{pH}$ 6.0) was used for antigen unmasking. Frozen sections were incubated with $4 \%$ PFA for $20 \mathrm{~min}$ at room temperature then washed in PBS and permeabilized with $0.3 \%$ Triton X-100 in PBS when necessary. Paraffin or frozen sections were blocked for $1 \mathrm{~h}$ with blocking buffer $\left(10 \%\right.$ serum in PBS) and incubated with primary antibody at $4^{\circ} \mathrm{C}$ overnight. The next day, sections were washed with PBS and incubated in Alexa Fluor 488-conjugated secondary antibodies (Jackson ImmunoResearch, 1:400) for $1 \mathrm{~h}$ at room temperature. To visualize nuclei, sections were stained with DAPI for $10 \mathrm{~min}$, and then washed with PBS and mounted in Fluoromount G (Electron Microscopy Sciences). ABC avidin/biotin method was used for Ki67 staining in paraffin section. The section was counterstained with hematoxylin (blue) to visualize nuclei. The following primary antibodies were used: Ki67 (Ventana); MBP (Aves Labs); Oct-6 (Santa Cruz Biotechnology); neurofilament (Developmen- tal Studies Hybridoma Bank). All the images were acquired using a fluorescence microscope with $10 \times / 0.4$ or $40 \times / 0.6$ objectives (Carl Zeiss). Acquisition software Image J was used.

Brdu incorporation and TUNEL assay. Pregnant mice were injected with bromodeoxyuridine (BrdU, Sigma-Aldrich; $50 \mathrm{mg} / \mathrm{kg}$ body weight) three times at $2 \mathrm{~h}$ intervals. Twenty-four hours later, mice were killed and sciatic nerves were dissected from pups at P0 or embryos at E18 and E19. Sciatic nerves were fixed with 4\% PFA overnight then processed into 6 $\mu \mathrm{m}$ frozen sections. Sections were stained with anti-Brdu antibody (Accurate Chemical, 1:500). Nuclei were stained with DAPI. BrdU-labeled cells and the DAPI nuclei were counted to define percentages of proliferating cells. TUNEL staining of control and mutant nerves were conducted by using an In Situ Cell Death Detection Kit, Fluorescein (Roche).

Schwann cell culture. Primary mouse SC cultures were obtained from postnatal day (P) 30 sciatic nerves. Sciatic nerves were sterilely dissected from killed $\mathrm{P} 30$ mice and cultured at $37^{\circ} \mathrm{C}, 7.5 \% \mathrm{CO}_{2}$ in DMEM medium (Invitrogen) supplemented with $10 \%$ fetal bovine serum (Gemini BioProducts), 1\% penicillin-streptomycin (Fisher Scientific), forskolin (2 $\mu \mathrm{M}$, Calbiochem), and $\beta$-heregulin (HRG, $10 \mathrm{ng} / \mathrm{ml}$, R\&D Systems). Pretreatment medium was replaced every $2 \mathrm{~d}$. After 6-9 d nerves were incubated in dissociation medium [Leibovitz medium (Invitrogen) containing collagenase type I ( $130 \mathrm{U} / \mathrm{ml}$, Worthington Biochemical Corporation), dispase II ( $2.5 \mathrm{mg} / \mathrm{ml}$, Roche Diagnostics), gentamycin $(50 \mu \mathrm{g} /$ $\mathrm{ml}$, Lonza) and fungizone $(2.5 \mu \mathrm{g} / \mathrm{ml}$, Invitrogen $)]$ for $3 \mathrm{~h}$ at $37^{\circ} \mathrm{C}$. Cells were dissociated using a narrowed Pasteur pipette and were then centrifuged for $5 \mathrm{~min}$ at $1000 \mathrm{rpm}$. Cells were resuspended in DMEM/ F-12 medium (Invitrogen) supplemented with N2 supplement solution (Invitrogen), forskolin ( $2 \mu \mathrm{M}$, Calbiochem), $\beta$-heregulin (HRG; $10 \mathrm{ng} / \mathrm{ml}$ ), gentamycin (50 $\mu \mathrm{g} / \mathrm{ml}$, Lonza), and fungizone $(2.5 \mu \mathrm{g} / \mathrm{ml}$, Invitrogen). Cells were plated on poly-L-lysine (Sigma-Aldrich) and laminin-coated (BD Bioscience) plates and incubated at $37^{\circ} \mathrm{C}, 7.5 \% \mathrm{CO}_{2}$. Medium was changed every $3 \mathrm{~d}$ and the cells were passaged when confluent. Cells were used at passages $0-1$.

Adenovirus infection and immunostaining. Cultured Prkarla flox/flox; lslRFP SCs at $50 \%$ confluence were treated with adenovirus-expressing Cre recombinase. The Crude adenovirus lysates were added in serum free medium (1:1) and incubated with cells for $6 \mathrm{~h}$. Cells were washed with PBS, and then cultured in SC culture medium. Adenovirus-expressing green fluorescence protein (GFP) was used as a control. Twenty-four hours after adenovirus infection, RFP was detectable in adeno-Cre infected Prkarla flox/flox; lslRFP SCs. These cells were cultured for up to $6 \mathrm{~d}$ and the cell growth and morphology were monitored by light microscopy. Cells were fixed and stained with antibodies recognizing the SC markers S100 $\beta$ (Dako) and P75NTR (Millipore).

$P K A$ activity assay. Passage one SCs were infected with GFP or Cre adenovirus. Forty-eight hours after infection cells were extracted for $10 \mathrm{~min}$ in ice-cold lysis buffer (20 mM 3-morpholinopropanesulfonic acid, $50 \mathrm{~mm}$ $\beta$-glycerolphosphate, $50 \mathrm{~mm}$ sodium fluoride, $1 \mathrm{~mm}$ sodium vanadate, $5 \mathrm{~mm}$ EGTA, 2 mм EDTA, 1\% NP40, 1 mm dithiothreitol, 1 mm benzamidine, 1 mu phenylmethane-sulfonylfluoride, and $10 \mu \mathrm{g} / \mathrm{ml}$ leupeptin and aprotinin). Supernatants were collected by centrifugation at $150,000 \times g$ for 30 min at $4^{\circ} \mathrm{C}$. Concentration of supernatant protein was measured by a protein assay kit (Bio-Rad). PKA activity was measured with a kinase assay kit (ENZO Life Science, catalog \#ADI-EKS-390A) using microplate wells precoated with a PKA substrate, according to the manufacture's protocol, with the addition of a wash step after stopping the reactions. The absorbance in reactions was measured at $450 \mathrm{~nm}$ in a microplate reader. Absorbance was divided by total protein $(\mu \mathrm{g})$ per sample and the data represented as relative PKA activity.

Morphometric quantification and statistical analysis. Total cell numbers in nerve cross sections were counted in semithin sections. Morphometric measurements of axonal sorting and myelination were performed in electron microscopic images of the nerve cross sections. A cell-counter plugin from ImageJ software was used to analyze the number of one-toone myelinated axons, and the axon number in each axonal bundle. Statistical significance was determined between two individual samples with the Student's $t$ test. For multiple comparisons, one-way ANOVA followed by Tukey's post hoc test was used. Significance was denoted as ${ }^{\star} p<0.05,{ }^{* *} p<0.01$, or ${ }^{* * *} p<0.001$. 
A

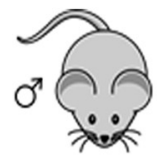

Dhh-cre;Prkarlafil

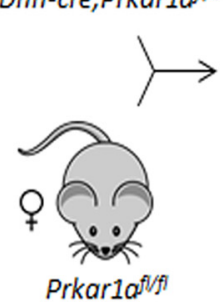

C

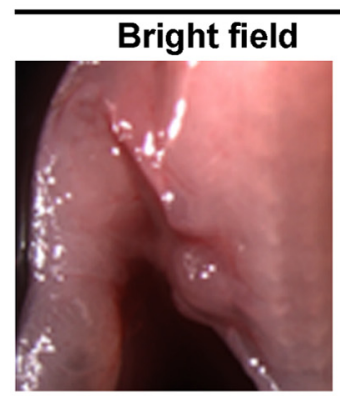

Prkar1a-SCKO

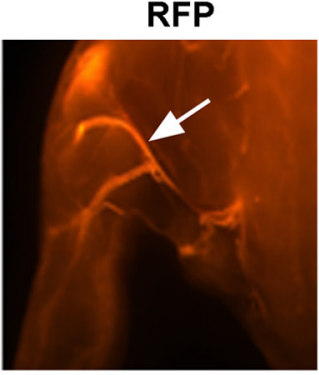

B

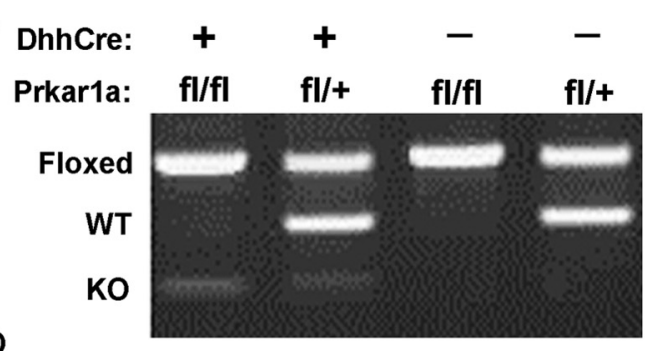

DhhCre

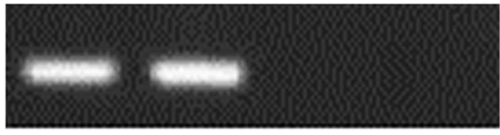

D

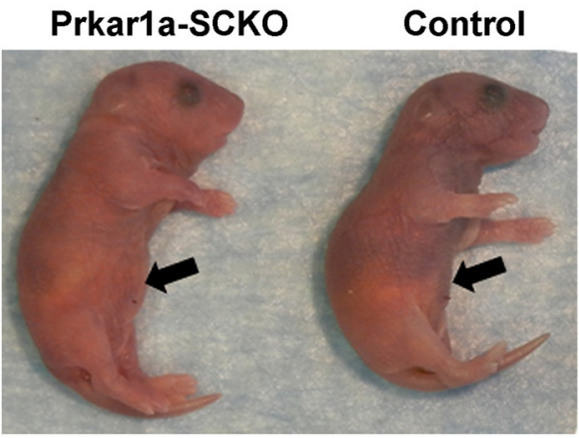

E
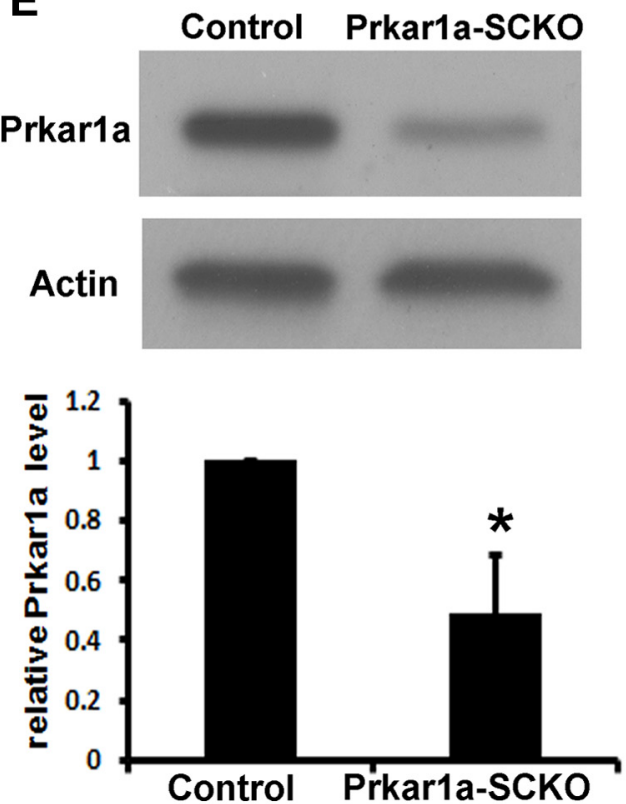

F
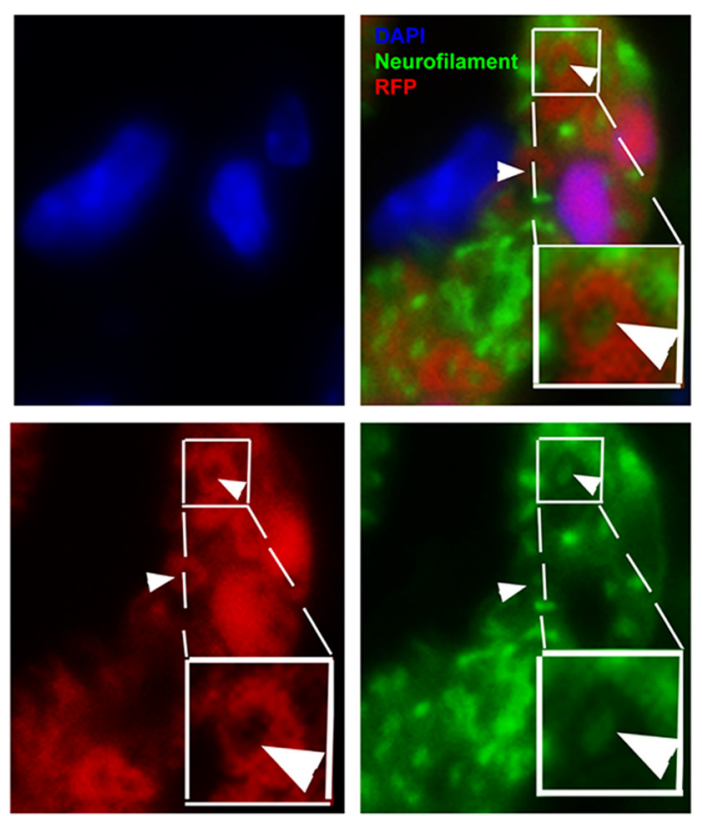

Figure 1. Generation and characterization of Prkar1a-SCKO mice. $A$, Mating scheme:fl, floxed conditional allele; + , wild-type (WT) allele. B, Genotyping. DhhCre, Prkar1a WT(+), floxed (fl), and deletion (KO) alleles in wild-type and Prkar1a-SCKO tails. The KO allele only appears in mice carrying DhhCre. C, Gross hindlimb of mutant pup, with RFP expression in Prkar1a-SCKO nerves (arrow) after Cre-mediated recombination. $\boldsymbol{D}$, Prkar1a-SCK0 mice are phenotypically indistinguishable from WT littermates. Pups have milk in their bellies (arrows). $\boldsymbol{E}$, Western blot showing reduction of Prkar1a protein levels in P0 mutant sciatic nerve lysates compared with wild-type nerves. For analysis, $n=$ independent blots from three nerves lysates for each genotype ${ }^{*} p<0.05$, Student's $t$ test). $\boldsymbol{F}$, Cross sections of Prkar1a-SCKO sciatic nerves at P0 stained with an axon marker, neurofilament (green). RFP (red) is expressed in Prkar1a-SCKO SCs after Cre-mediated recombination. Axons were not RFP-positive (arrowhead). Nuclei are visualized by DAPI (blue).

\section{Results}

Conditional knock-out of Prkarla in SCs in vivo

To analyze the role of Prkarla in SCs in vivo, Prkarla conditional knock-out mice (Prkarla-SCKO) were generated using the Cre recombinase-LoxP system under the control of the desert hedgehog (Dhh) gene. In these mice, Dhh activates Cre recombinase expression in SCPs at day E12.5 (Jaegle et al., 2003; Wu et al., 2008). Prkarla ${ }^{\text {flox/flox }}$ mice were bred with Dhh-Cre Prkarla ${ }^{+/-}$ mice (Fig. 1A). The Prkarla knock-out alleles were confirmed by PCR (Fig. 1B). We introduced a lox-STOP-lox red fluorescent protein (lslRFP) allele as a Cre recombination reporter (Madisen et al., 2010). RFP was expressed in Cre-positive peripheral nerves 
A

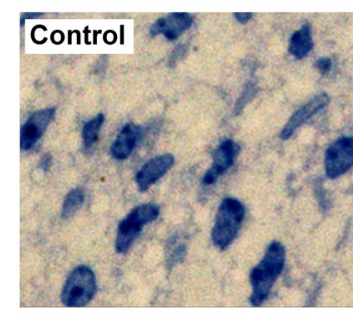

B

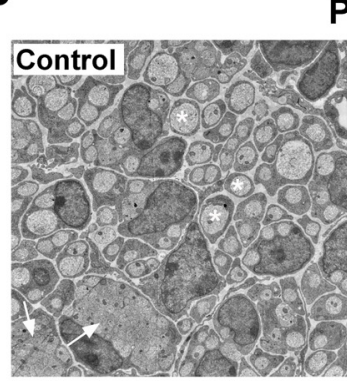

F

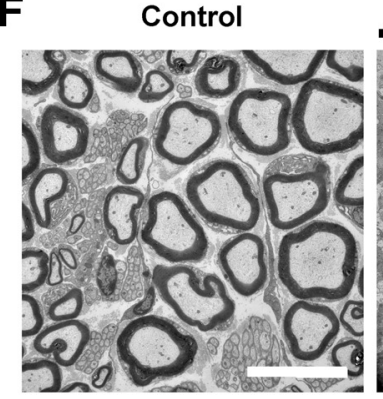

Po

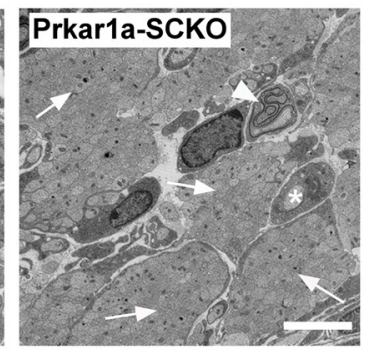

C

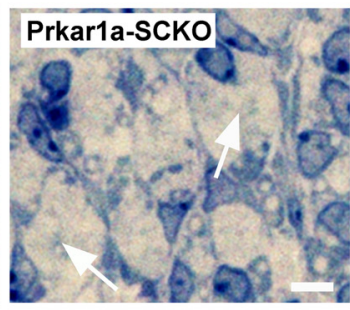

E
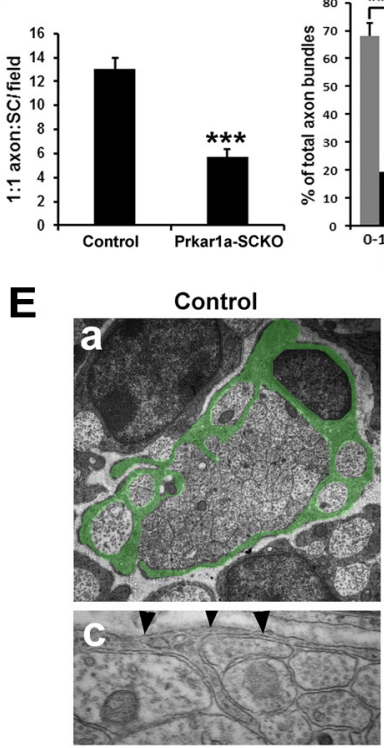

Prkar1a-SCKO
D

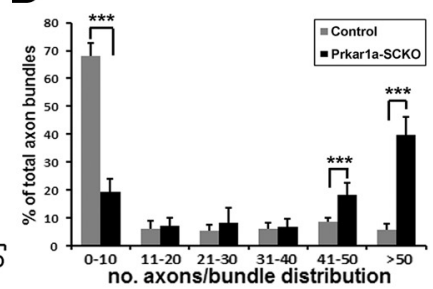

Prkar1a-SCKO

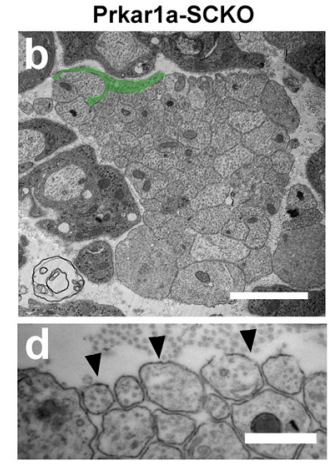

P25
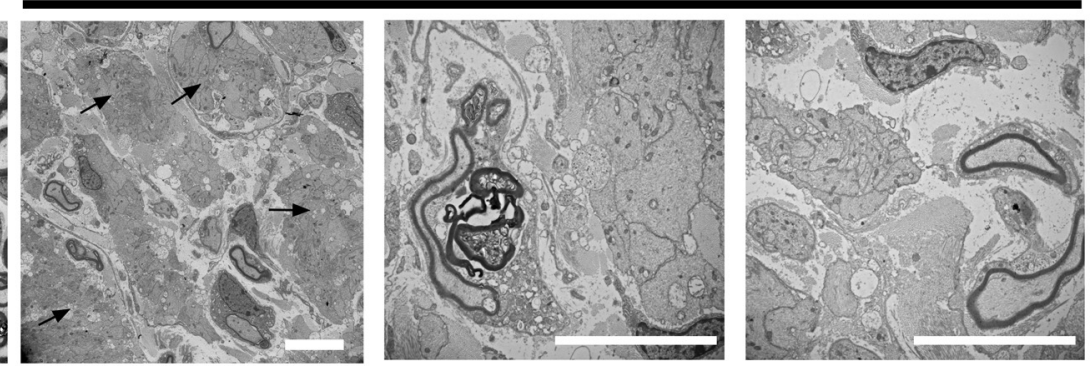

Figure 2. Axonal sorting defects in Prkar1a-SCKO sciatic nerve. A, Semithin cross sections of Prkar1a-SCKO sciatic nerves at PO. B, Electron microscopy (EM) analysis of control and Prkar1a-SCKO sciatic nerves cross-sections at P0. Unsorted axonal bundles (arrow) and SC:axon in 1:1 relationships (asterisk) are denoted. C, Decrease in the number of 1:1 SC-axon bundles in Prkar1a-SCK0 sciatic nerves. $\boldsymbol{D}$, Axon bundles in Prkar1a-SCKO sciatic nerves contain more axons per bundle. $\boldsymbol{C}, \boldsymbol{D}$, For each genotype, $n=4$ mice $\left({ }^{* * *} p<0.001\right.$, Student's $t$ test). Error bars indicate \pm SEM. $\boldsymbol{E}$, EM of axonal bundles from control $(E \boldsymbol{E}, \boldsymbol{E C})$ and Prkar1a-SCKO (Eb, Ed) sciatic nerves at PO.SC processes are highlighted with artificial color (green). Ec, Ed, High-magnification micrographs of the edges (arrowheads) of axonal bundles from control (EC) and Prkar1a-SCK0 sciatic nerves (Ed). $\boldsymbol{F}$, EM analysis of sciatic nerves cross-sections from control and a rare surviving Prkar1a-SCK0 mouse at P25. Unsorted axon bundles (arrows) were present in this P25 Prkar1a-SCKO mouse. Scale bars: $\boldsymbol{A}, \boldsymbol{B}, 5 \mu \mathrm{m}$; (in Eb) Ea, Eb, $2 \mu \mathrm{m}$; (in Ed), Ec, Ed, $500 \mathrm{~nm}$; $\boldsymbol{F}, 10 \mu \mathrm{M}$.

(Fig. 1C). Conditional knock-out of Prkarla beginning in SCPs did not cause embryonic lethality or obvious developmental defects in pups at birth (Fig. 1D). More than $90 \%$ of Prkar 1a-SCKO mice died within $48 \mathrm{~h}$ after birth. Of 20 litters, only three mice survived to weaning age, and all three were severely runted and exhibited seizure-like activity requiring euthanasia by day 25 . The cause of death remains unknown; milk was present in pup stomachs, and pups appeared to breathe normally. Reduction of Prkarla protein expression in the sciatic nerves of mutant pups was verified by Western blot (Fig. 1E). Residual Prkarla protein in mutant nerves is likely caused by its expression in fibroblasts and/or axons. RFP expression was present in SCs but not in neurofilament stained axons (Fig. $1 F$ ), consistent with a previous study showing that DhhCre is expressed in SCs and satellite cells but not neurons in dorsal root ganglia (Williams et al., 2008).

\section{Radial sorting defects in Prkarla-SCKO sciatic nerves}

Prkarla-SCKO sciatic nerves were compared with control nerves in semithin plastic cross sections. At E18 (data not shown) and at $\mathrm{P} 0$, large abnormal axon bundles were observed in Prkarla-SCKO sciatic nerves (Fig. 2A). By electron microscopy, in control nerves many axons had already formed 1:1 relationships with SC. In contrast, numerous axonal bundles containing large numbers of axons were observed in PrkarlaSCKO sciatic nerves at P0 (Fig. 2B). SC nuclei penetrated axon bundles in control nerves, but in Prkarla-SCKO nerves SC nuclei remained outside axon bundles, a characteristic of earlier stages of nerve development. Quantification confirmed a sorting defect; the number of SCs in 1:1 relationship with axons was significantly decreased in Prkarla-SCKO sciatic nerves at P0 (Fig. 2C), and 70\% of axon bundles in PrkarlaSCKO sciatic nerves contained $>20$ axons within each bundle (Fig. 2D). Unsorted axonal bundles persisted through postnatal day 25 in sciatic nerves from a rare surviving PrkarlaSCKO mouse (Fig. $2 F$ ), confirming a radial sorting defect rather than a maturation delay in Prkarla-SCKO SCs.

We observed another abnormality in electron micrographs of Prkarla-SCKO sciatic nerves. In axon bundles of control nerves, SC processes surround axons, isolating individual axons from the environment. However, Prkarla-SCKO SCs failed to surround axon bundles (Fig. 2E). Thus, axons in Prkarla-SCKO nerves were largely exposed to the environment and were in contact with endoneurial collagen (Fig. 2E). This observation suggests that SCs fail to extend normal processes in Prkar1a-SCKO nerves in vivo. 
A

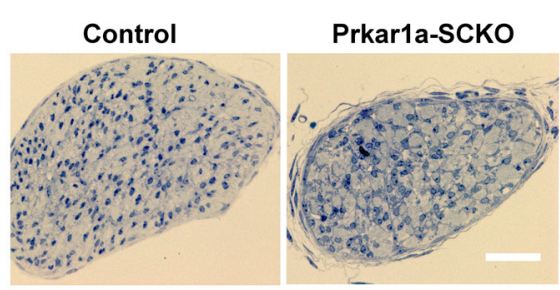

C

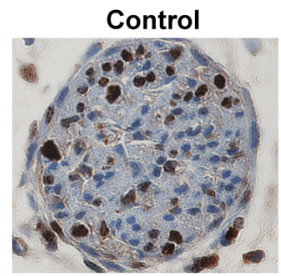

E

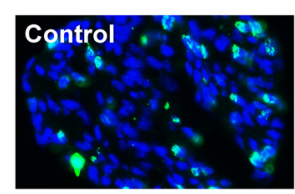

G

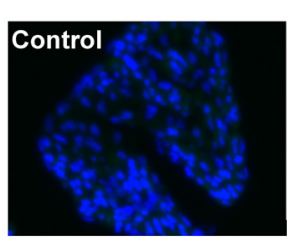

Prkar1a-SCKO
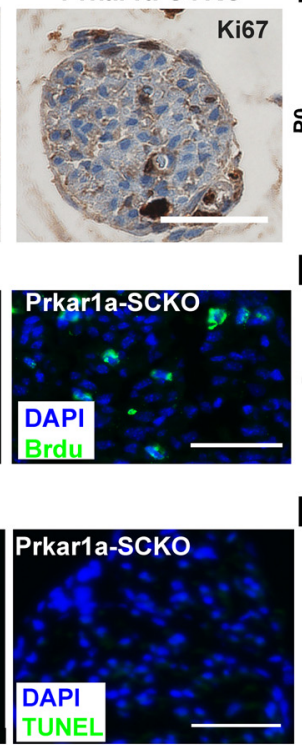

B

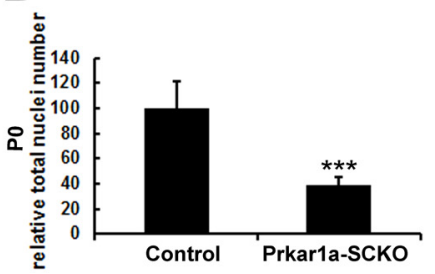

D

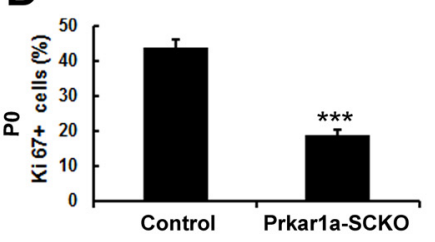

$\mathbf{F}$

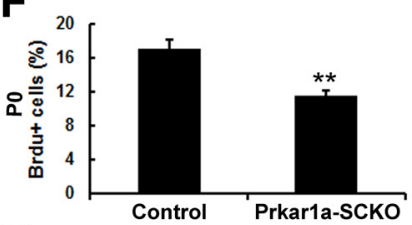

H

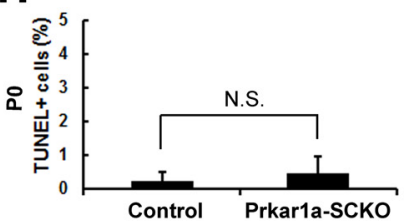

Figure 3. Reduced proliferation in Prkar1a-SCKO sciatic nerves. $\boldsymbol{A}$, Semithin cross sections. $\boldsymbol{B}$, Nuclei numbers in Prkar1a-SCKO sciatic nerves are significantly decreased at PO. C, Paraffin cross sections from control and Prkar1a-SCKO nerve stained with Ki67; DAB was used as the chromogen (brown). The section was counterstained with hematoxylin (blue) to visualize nuclei. $\boldsymbol{D}$, The percentage of Ki67-positive cells is significantly decreased in Prkar1a-SCKO nerves. E, Cross sections from control and Prkar1a-SCKO nerve stained with anti-BrdU. $\boldsymbol{F}$, Significant increases in percentage of BrdU + cells in Prkar1a-SCKO nerves. G, Paraffin cross sections from control and Prkar1a-SCKO nerve stained with TUNEL. $\boldsymbol{H}$, No difference in percentage of TUNEL + cells in control and Prkar1a-SCKO nerves. For each genotype, $n=4$ mice $\left({ }^{* *} p<0.01,{ }^{* * *} p<0.001\right.$, Student's $t$ test). Error bars indicate \pm SEM. Scale bars, $50 \mu \mathrm{m}$.

Prkar1a knock-out inhibits SC proliferation

SCs proliferate extensively during radial sorting to match SC numbers to numbers of axons to be ensheathed and/or myelinated. Radial sorting abnormalities in Prkarla-SCKO nerves correlated with deficiencies in the number of SCs. Nuclei numbers in semithin cross sections of Prkarla-SCKO sciatic nerves were significantly decreased compared with control sciatic nerves (Fig. $3 A, B)$. Decreased proliferation or increased cell death could underlie decreased cell numbers in Prkarla-SCKO nerves. Thus, we analyzed SC proliferation, and found less Ki67 staining in Prkarla-SCKO nerve cross sections compared with wild-type nerve (Fig. 3C). The percentage of Ki67-positive cells (those in the cell cycle) was significantly decreased in Prkarla-SCKO nerves at P0 (Fig. 3D). Reduced proliferation was confirmed by the decreased percentage of Brdu-positive cells (monitoring entry into S-phase of the cell cycle) in Prkarla-SCKO nerves (Fig. $3 E, F)$. In contrast, apoptotic cell death was unaffected by Prkarla knock-out; there was no difference in percentage of TUNEL+ cells in control versus Prkarla-SCKO nerves (Fig. $3 G, H)$. Thus, radial sorting impairment in Prkarla-SCKO correlates with reduced SC proliferation, and insufficient available cells to complete radial sorting in the absence of Prkarla. This mirrors prior data showing decreased proliferation during organogenesis in a cardiac-specific KO of Prkarla (Yin et al., 2008).

The onset of myelination is earlier in Prkar1a-SCKO sciatic nerves

In addition to axonal sorting defects in Prkarla-SCKO sciatic nerves, myelin sheaths formed early in those SCs in 1:1 relationship with axons. At E18 in control nerves the few myelinating SCs present have loose uncompact myelin, whereas mutant SCs already had compact myelin (Fig. 4A). Quantification showed that there was a significant increase in myelinated fibers in E18-P0 Prkar1a-SCKO sciatic nerves compared with wild-type controls (Fig. 4D). Myelination in SCs is controlled by transcription factors, including Oct6, which initiates the transition from ensheathing, promyelinating SCs to myelinating cells; cAMP regulates Oct6 expression in SCs (Monuki et al., 1989). We reasoned that if cAMP/PKA signaling was increased in Prkarla null SCs, this might upregulate Oct6 expression. Indeed, we detected a dramatic increase of Oct6 expression in most or all SCs in Prkarla-SCKO sciatic nerves compared with control nerves at E18 (Fig. 4B), suggesting that Prkarla is important to time the onset of myelination. Consistent with this finding, expression of a myelin marker, MBP, was increased in scattered cells, likely those in 1:1 relationships with axons, in Prkarla-SCKO sciatic nerves at E18 compared with control sciatic nerves (Fig. 4C). Western blots show that MBP and peripheral myelin protein 22 (PMP22) were increased, whereas Krox20 expression was slightly decreased in Prkarla-SCKO sciatic nerves (Fig. 4E). However, although expression of MBP was accelerated in Prkarla-SCKO nerves, and few myelin sheaths formed early in those SCs in 1:1 relationship with axons in Prkarla-SCKO sciatic nerves, this did not translate into presence of large numbers of myelinated fibers in a rare Prkarla-SCKO nerve analyzed at P25 (Fig. 2F). The altered SC differentiation status (Oct6+;MBP - or Oct6 $+; \mathrm{MBP}+)$ may contribute to the failure of axon sorting and decrease in cell proliferation.

The failure to ensheath axons might be responsible, at least in part, for the observed decreased SC proliferation. Axons normally stimulate SC proliferation via ErbB2/ErbB3 receptors that activate PI3K and MAPK signaling. Total ErbB3 expression and phosphorylation of Akt and Erk1/2 were reduced in PrkarlaSCKO sciatic nerves (Fig. $4 E$ ), consistent with a failure of axonmediated proliferation in Prkarla-SCKO.

Cell autonomous reduced cell growth and abnormal cell morphology in Prkarla-SCKO SCs in vitro

We cultured primary SCs from P30 sciatic nerves from Prkarl $a^{\text {floxfllox; }}$;slRFP mice to further define cell autonomous effects of Prkarla. We used Cre adenovirus to infect SC and knockout Prkarla in vitro; control cells were infected with adenovirus encoding GFP. RFP was expressed by $24 \mathrm{~h}$ after adeno-Cre infection in Prkarla flox/flox; lslRFP SCs, whereas control adenovirus infected GFP-expressing cells were green (Fig. 5A). Western 
A
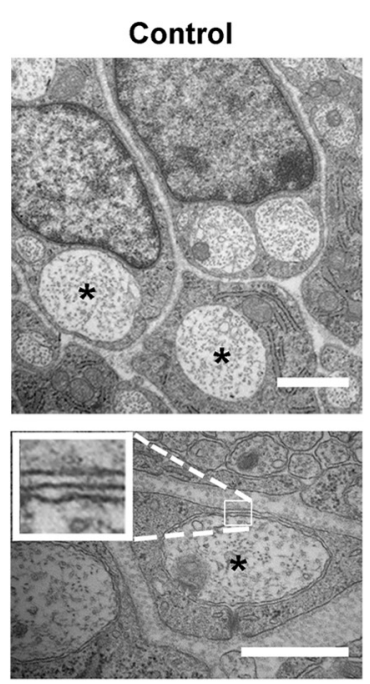

B

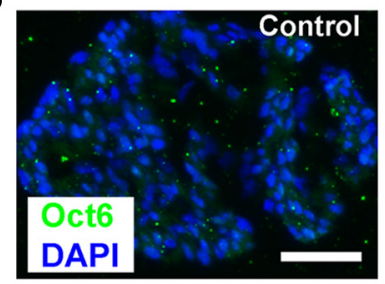

C

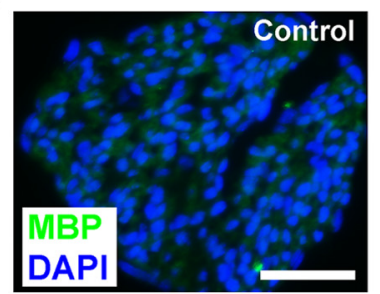

Prkar1a-SCKO
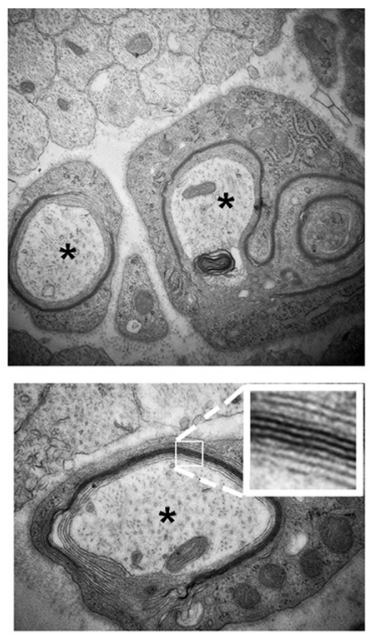

D
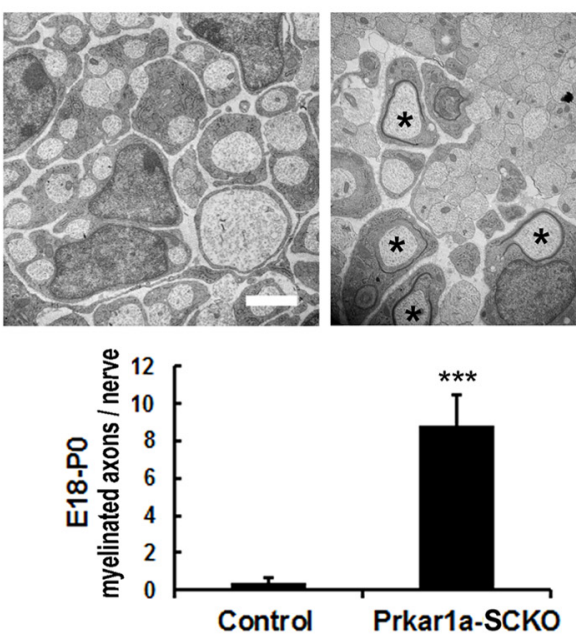

Prkar1a-SCKO

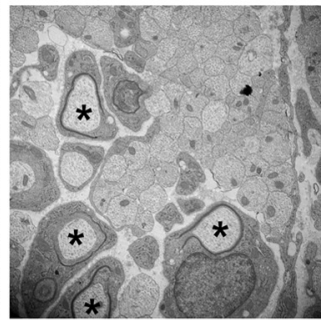

ErbB3

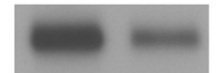

P-Akt

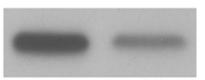

Krox20

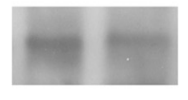

Akt

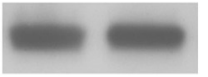

MBP

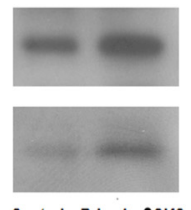

Control Prkarla.SCKO

Pmp22
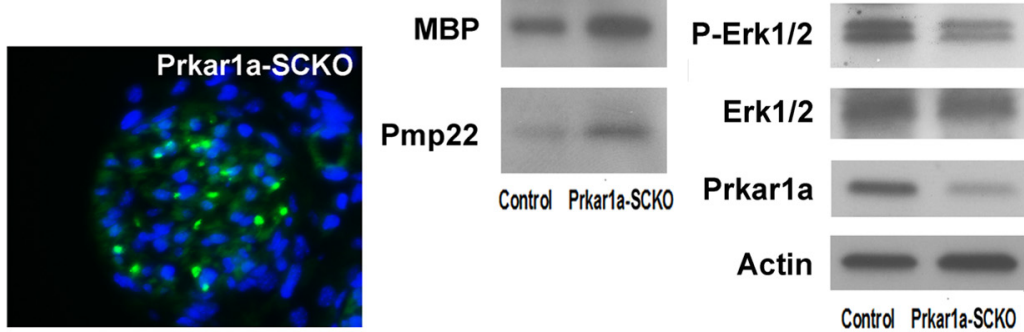

Figure 4. The onset of myelination is early in Prkar1a-SCKO sciatic nerves. $A$, EM shows 1:1 SC-axon relations (asterisks) in control and Prkar1a-SCK0 sciatic nerves at E18. Bottom, more myelin wraps were present in Prkar1a-SCK0 sciatic nerves. B, Oct6 expression was increased in Prkar1a-SCK0 sciatic nerves stained with anti-0ct6. $\boldsymbol{C}$, MBP expression was increased in E18 Prkar1a-SCK0 sciatic nerves. D, EM shows myelinated axons (asterisks) in Prkar1a-SCK0 sciatic nerves at P0. There was a significant increase in myelinated axons in E18-P0 Prkar1a-SCK0 nerves. For each genotype, $n=6$ mice at E18-PO $\left({ }^{* * *} p<0.001\right.$, Student's $t$ test). Error bars indicate \pm SEM. E, MBP and Pmp22 expression were increased, whereas Krox20 was slightly decreased in Prkar1a-SCK0 sciatic nerve lysates. Total ErbB3, P-Akt, and P-Erk1/2 were decreased in Prkar1a-SCKO sciatic nerve lysates by Western blot $(n=3)$. $\beta$-Actin was used as a loading control. Scale bars: $\boldsymbol{A}, 1 \mu \mathrm{m} ; \boldsymbol{B}$, C, $25 \mu \mathrm{m} ; \boldsymbol{D}, 2 \mu \mathrm{m}$.

blots confirmed the absence of Prkarla protein $2 \mathrm{~d}$ after adeno-Cre infection (Fig. 5B). To test whether PKA activity is altered in Prkarla-KO SCs, we measured PKA activity by a kinase assay $2 \mathrm{~d}$ after adenovirus infection. Basal PKA activity was increased two-fold in Prkarla-KO SCs compared with GFP infected control SCs (Fig. 5C); a similar two-fold increase in PKA activity was observed after forskolin stimulation in Prkarla-KO SCs compared with GFP infected control SCs (data not shown). We monitored cells for up to $6 \mathrm{~d}$ after adeno-Cre infection. Consistent with inhibition of proliferation in Prkarla-SCKO nerves in vivo, numbers of cells in Prkarla knock-out SC cultures decreased significantly compared with control SC cultures (Fig. 5D,E). The Prkarla cells detached rapidly over time after infection, but there was no significant apoptosis as measured by cleaved caspase 3 (data not shown), supporting the idea that cells die by anoikis.

Cell morphology was also changed by Prkarla knock-out in SC in vitro (Fig. $5 F$ ). Wild-type SCs normally extend two long processes and develop bipolar morphology in culture. Many Prkarla knock-out SCs had multiple processes and formed nu- merous branches (Fig. 5F). The cells with abnormal morphology in Prkarla knock-out culture were SCs, as confirmed by staining with antibodies recognizing SC markers S100 $\beta$ and P75NTR (Fig. 5G).

The absence of Prkarla regulatory subunits resulted in high PKA activity in vitro. We added the PKA inhibitor PKI $12 \mathrm{~h}$ after adeno-Cre infection to SC cultures, which decreased the occurrence of abnormal multiple processes (Fig. $5 H$ ). In addition, Prkarla knock-out SCs formed fewer lamellipodia compared with control cells (Fig. 5I).

\section{Discussion}

Despite significant in vitro data supporting the importance of cAMP in promoting SC proliferation and myelination (Jessen and Mirsky, 1991; Morgan et al., 1991), effects of PKA signaling on SC proliferation had not been analyzed in vivo. Here, we studied the in vivo role of PKA signaling in SC using a new mouse model in which Prkarla is lost beginning at the SCPs stage of development. Conditional Prkarla knock-out resulted in a dramatic and persistent axonal sorting defect, and unexpectedly de- 
A

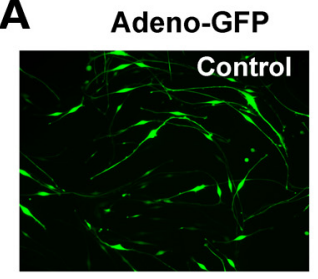

$\mathbf{B}$

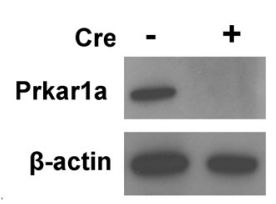

E

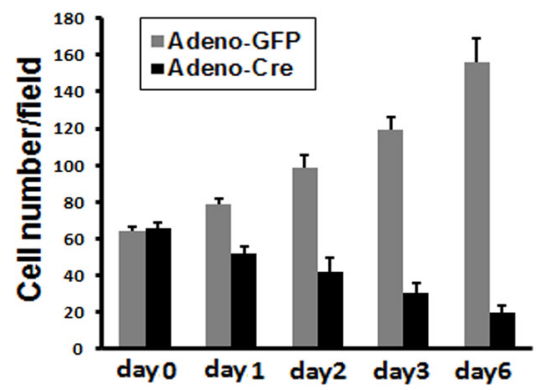

C
D
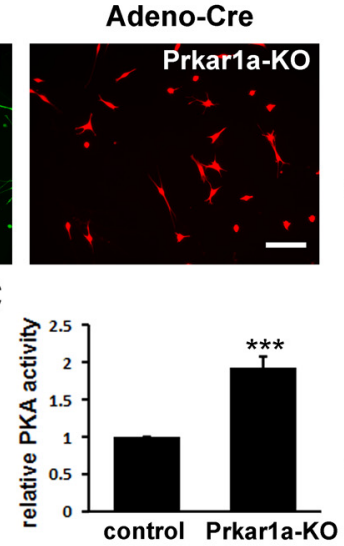

day3

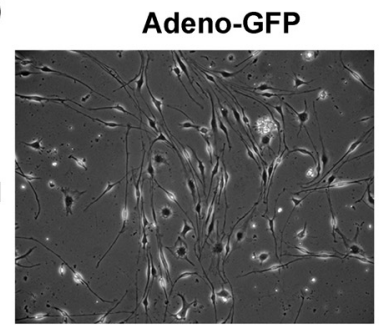

day6
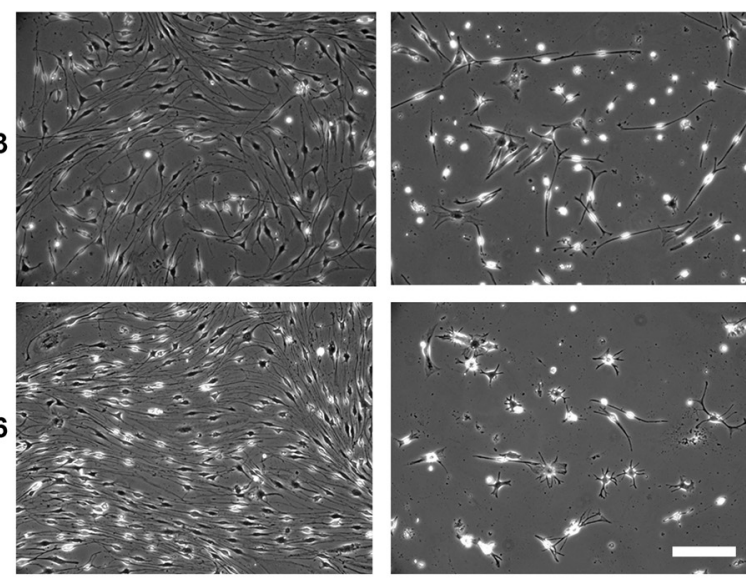

F
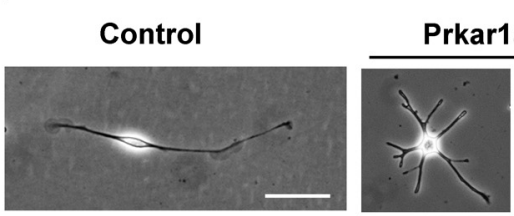

G
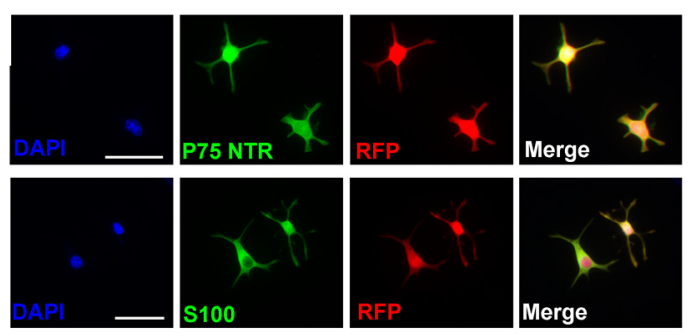

H
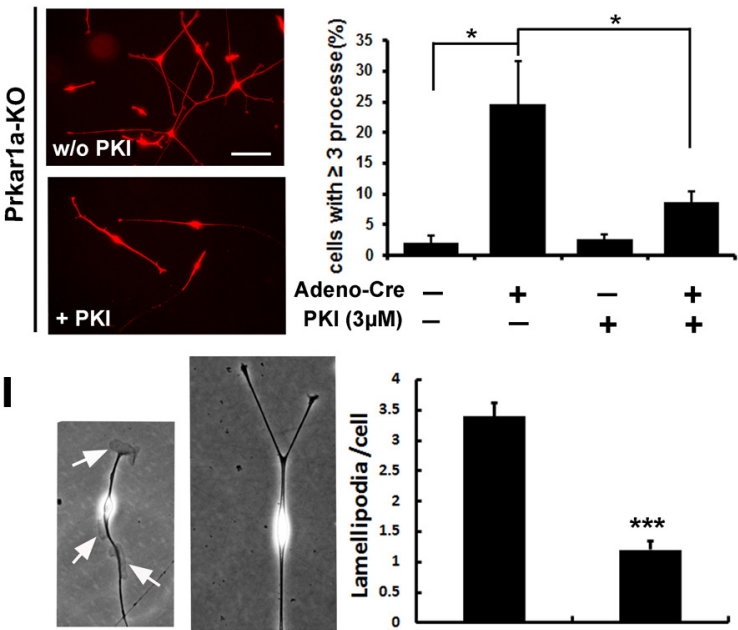

Adeno-GFP

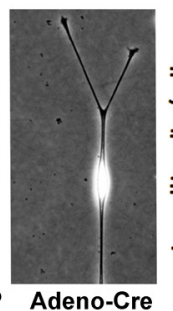

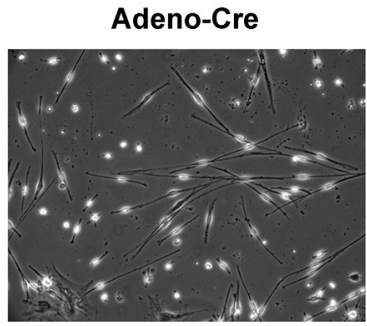
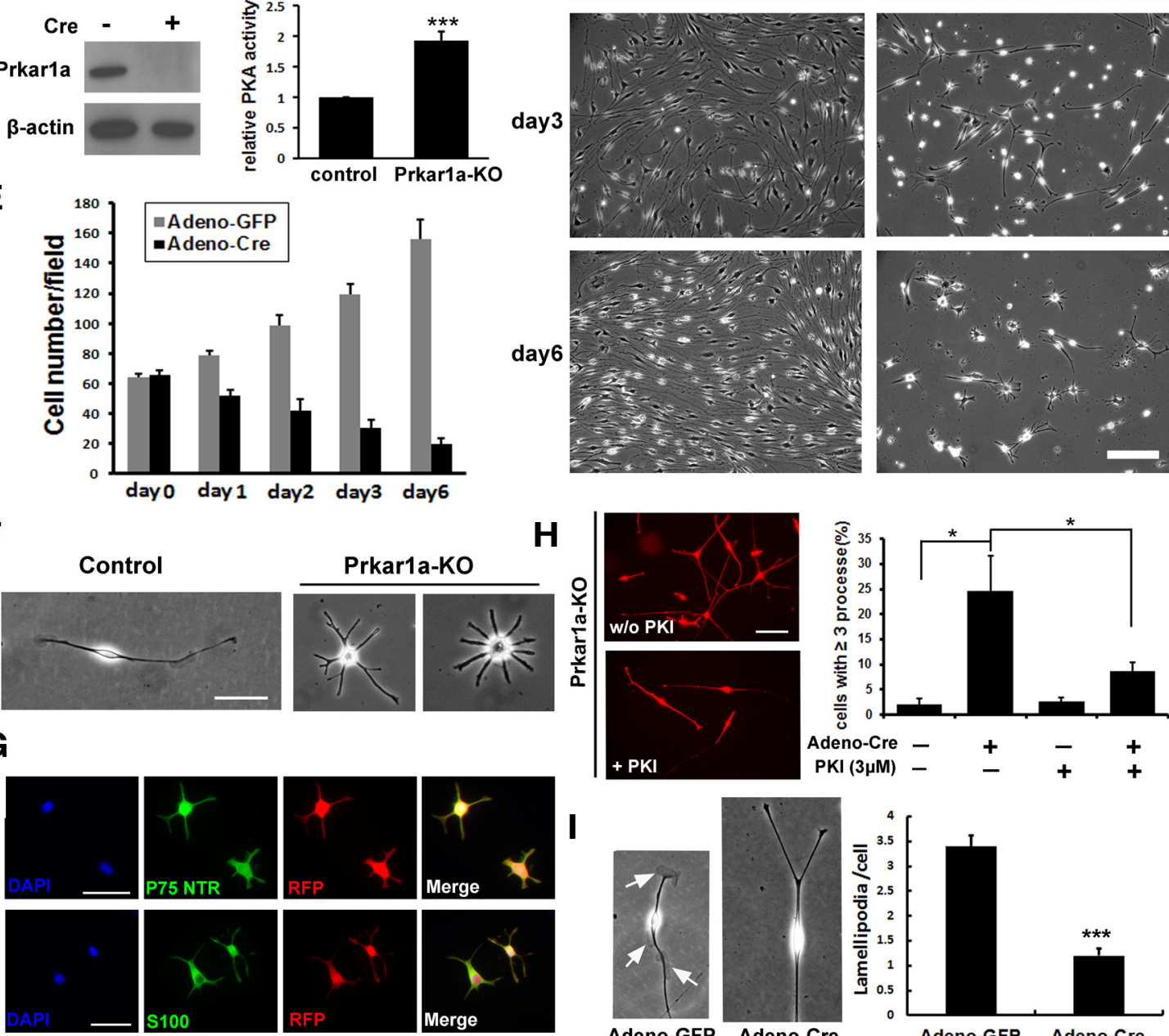

Figure 5. Prkar1a knock-out affects SC morphology. A, Cultured primary SCs from P30 sciatic nerves from Prkar1 $a^{\text {loxp/loxp } ; ~ I s I R F P ~ m i c e . ~ R F P ~ w a s ~ e x p r e s s e d ~ b y ~} 24 \mathrm{~h}$ after adeno-Cre infection in Prkar1a-KO SCS, whereas control adenovirus infected GFP-expressing cells were green. B, Prkar1a expression was reduced in Cre adenovirus infected SCS compared with GFP infected SCs (2 d after infection) by Western blot. $\beta$-Actin was used as a loading control. C, PKA activity was significantly increased in Prkar1a-KOSCS. $n=3$ independent experiments done in duplicate. D, SC cultures were monitored for $6 \mathrm{~d}$ after infection. $\boldsymbol{E}$, Cell numbers in Prkar1a-KO SCs were significant reduced compared with control SCs. $n=30$ fields from three independent experiments. $\boldsymbol{F}$, Phase micrographs of control and Prkar1a knock-out SCS. G, Prkar1a knock-out cells stained with SC markers S100 $\beta$ or P75NTR. H, PKA inhibitor PKI treatment partially rescued abnormal cell morphology in Prkar1a knock-out cultures. I, Prkar1a knock-out SCs contain fewer lamellipodia (arrow) compared with control cells. $n=60$ cells from three independent experiments $\left({ }^{*} p<0.05\right.$, ${ }^{* * *} p<0.001 ; 0 n e-w a y$ ANOVA followed by Tukey's post hoc test). Error bars indicate \pm SEM. Scale bars: $A, C, 100 \mu \mathrm{m}$.

creased SC proliferation in Prkarla-SCKO nerves in vivo. In Prkarla-SCKO SCs sorted into 1:1 relationships with axons in vivo, myelination began prematurely, correlating with an increase in a cAMP-regulated transcription factor Oct-6 expression and increased MBP expression.

The absence of Prkarla regulatory subunits is predicted to unleash PKA catalytic subunits, resulting in high PKA activity during SC development in vivo. We confirmed a two-fold increase in PKA activity in Prkarla-KO SCs. Consistent with effects of Prkarla loss causing high PKA activity and cell phenotypes, we were able to partially reverse some abnormalities in Prkarla-KO cells with a weak inhibitor of PKA, PKI (Guergnon et al., 2006).
The high expression of the Oct6 transcription factor in Prkarla mutant nerves provides additional evidence that PKA activity is upregulated in the mutant nerves. We therefore infer that high cAMP/PKA signaling in Prkarla-SCKO SC inhibited SC proliferation in vivo, and that high CAMP/PKA activity negatively regulates SC proliferation. Consistent with our results, at low levels of cAMP activation, the SC mitogen NRG1 promotes SC proliferation, whereas a higher concentration of cAMP reduced SC proliferation and promoted differentiation (Arthur-Farraj et al., 2011). In addition, infection of SCs with dominant negative PKA effectively blocked forskolin-stimulated SC mitosis (Howe and McCarthy, 2000). However, we cannot formally exclude Prkarla 
functions outside the PKA holoenzyme in the phenotypes we describe.

The abnormal multiple processes we identified in PrkarlaSCKO SCs are caused at least in part by high PKA activity in Prkarla knock-out SCs because the PKA inhibitor PKI substantially prevented the occurrence of this phenotype. However, neither reduced lamellipodia formation in Prkarla-SCKO SCs nor SC growth were rescued by the weak PKA inhibitor PKI (data not shown). It is possible that precise levels of PKA might rescue function. It is likely that highly regulated levels of PKA are necessary at precise times in development to coordinate radial sorting with SC proliferation and differentiation and maintain the balance between SC proliferation and differentiation in vivo, as predicted by in vitro studies.

Supporting the idea that Prkarla is relevant in SCs, inactivating mutations in PRKAR1A are found in patients with Carney complex (CNC; Kirschner et al., 2000), some of whom develop peripheral nerve tumors, schwannomas (Stratakis, 2002; Stergiopoulos and Stratakis, 2003). Indeed, mice heterozygous for Prkarla mutations or those with tissue-specific ablation in subset of mouse cranial neural crest cells developed schwannomas (Kirschner et al., 2005; Jones et al., 2008). In contrast to our observation that Prkarla loss reduces SC proliferation when expressed beginning at the SC precursor stage of development, specific knock-out of Prkarla in a subset of mouse facial neural crest cells increased SCs proliferation and induced schwannoma formation (Jones et al., 2008). These intriguing data suggest that either PKA activity has opposite effects on SC proliferation in different developmental cell contexts and/or that additional genetic events are necessary to promote tumorigenesis in Carney complex.

Our data reveal a previously unknown function of Prkarla in SC radial sorting. In part, the observed failure of radial sorting may be secondary to decreased SC numbers in Prkarla-SCKO nerves. We believe that it is likely that additional factors also contribute to the radial sorting defect, because SCs present in nerve failed to extend processes into axon bundles to segregate axons, and Prkarla-SCKO SCs in vitro showed abnormal cell morphology. These in vitro morphology changes correlate with failure of SC radial sorting in the Prkarla-SCKO nerves. Cell morphology is largely controlled by remodeling of the actin cytoskeleton through Rho GTPases, GTP-binding proteins (Rho, Rac, and $c d c 42)$ that activate downstream kinases when GTPbound. Each of the Rho family GTPases has been implicated in aspects of axonal sorting, SC proliferation and/or myelination (Melendez-Vasquez et al., 2004; Feltri et al., 2008; Krause et al., 2008). In the absence of Prkarla, it is plausible that active PKA phosphorylates proteins that regulate Rho signaling. Racl activity was upregulated in SCs when Prkarla was ablated in neural crest cells (Jones et al., 2008; Manchanda et al., 2013). PKA phosphorylates GTP dissociation inhibitor to negatively regulate Rho activity (Qiao et al., 2008), and can directly phosphorylate Rho (Jones and Palmer, 2012). PKA phosphorylates the Rac-GEF IQGAP2, enhancing Rac inactivation (Logue et al., 2011). Cdc42 might also be involved, as PKA can result in translocation of the exchange factor $\beta 1$-PIX and Cdc42 activation (Chahdi et al., 2005).

The expression of Oct6, an important transcription factor in SC myelination, was dramatically increased in Prkarla-SCKO nerves. Oct6 was expressed in all nerve SCs consistent with a major role for PKA in regulation of Oct6 expression in vivo. The altered SC differentiation status (Oct6+;MBP + or Oct6+; $\mathrm{MBP}-$ ) of perinatal SCs may contribute to the observed failure of axon sorting and decrease in cell proliferation. Notably, although expression of MBP was accelerated in Prkarla-SCKO nerves, only a few myelin sheaths formed early in Prkarla-SCKO sciatic nerves, although this did not translate into presence of large numbers of myelinated fibers in a rare Prkarla-SCKO nerve analyzed at P25. We were unable to generate mice to determine whether Oct6 expression persists past the perinatal period in Prkarala-SCKO nerves, but our results are consistent with a study showing that persistent Oct6 expression can result in hypomyelination (Ryu et al., 2007).

It is likely that highly regulated levels of PKA coordinate radial sorting with SC proliferation and differentiation. In particular, precise levels of cAMP are likely to maintain the balance between SC proliferation and differentiation in vivo, as predicted by in vitro studies. In this context, it will be interesting to test whether SC proliferation is increased in Gpr126 knock-out mice or Rac1CKO mice that have low cAMP/PKA signaling (Monk et al., 2011; Guo et al., 2012). In conclusion, we have identified a critical role for the R1a subunit of PKA in regulation of peripheral nerve SC development. Prkarla controls process extension by SCs and radial sorting in nerve development, as well as SC numbers and timing of expression of myelin genes in peripheral nerves.

\section{References}

Amieux PS, Howe DG, Knickerbocker H, Lee DC, Su T, Laszlo GS, Idzerda RL, McKnight GS (2002) Increased basal cAMP-dependent protein kinase activity inhibits the formation of mesoderm-derived structures in the developing mouse embryo. J Biol Chem 277(30):27294-27304. CrossRef Medline

Arthur-Farraj P, Wanek K, Hantke J, Davis CM, Jayakar A, Parkinson DB, Mirsky R, Jessen KR (2011) Mouse schwann cells need both NRG1 and cyclic AMP to myelinate. Glia 59:720-733. CrossRef Medline

Barradeau S, Imaizumi-Scherrer T, Weiss MC, Faust DM (2002) Intracellular targeting of the type-I alpha regulatory subunit of cAMP-dependent protein kinase. Trends Cardiovasc Med 12:235-241. CrossRef Medline

Bossis I, Stratakis CA (2004) Minireview: PRKAR1A: normal and abnormal functions. Endocrinology 145:5452-5458. CrossRef Medline

Chahdi A, Miller B, Sorokin A (2005) Endothelin 1 induces beta 1Pix translocation and $\mathrm{Cdc} 42$ activation via protein kinase A-dependent pathway. J Biol Chem 280:578-584. CrossRef Medline

Cheng X, Ji Z, Tsalkova T, Mei F (2008) Epac and PKA: a tale of two intracellular cAMP receptors. Acta Biochim Biophys Sin (Shanghai) 40:651662. CrossRef Medline

Davis JB, Stroobant P (1990) Platelet-derived growth factors and fibroblast growth factors are mitogens for rat Schwann cells. J Cell Biol 110:13531360. CrossRef Medline

Feltri ML, Suter U, Relvas JB (2008) The function of RhoGTPases in axon ensheathment and myelination. Glia 56:1508-1517. CrossRef Medline

Guergnon J, Dessauge F, Traincard F, Cayla X, Rebollo A, Bost PE, Langsley G, Garcia A (2006) A PKA survival pathway inhibited by DPT-PKI, a new specific cell permeable PKA inhibitor, is induced by T. annulata in parasitized B-lymphocytes. Apoptosis 11:1263-1273. CrossRef Medline

Guo L, Moon C, Niehaus K, Zheng Y, Ratner N (2012) Racl controls Schwann cell myelination through cAMP and NF2/merlin. J Neurosci 32:17251-17261. CrossRef Medline

Howe DG, McCarthy KD (2000) Retroviral inhibition of cAMP-dependent protein kinase inhibits myelination but not Schwann cell mitosis stimulated by interaction with neurons. J Neurosci 20:3513-3521. Medline

Jaegle M, Ghazvini M, Mandemakers W, Piirsoo M, Driegen S, Levavasseur F, Raghoenath S, Grosveld F, Meijer D (2003) The POU proteins brn-2 and oct- 6 share important functions in Schwann cell development. Genes Dev 17:1380-1391. CrossRef Medline

Jessen KR, Mirsky R (1997) Embryonic Schwann cell development: the biology of Schwann cell precursors and early Schwann cells. J Anat 191:501505. Medline

Jessen KR, Mirsky R (1991) Schwann cell precursors and their development. Glia 4:185-194. CrossRef Medline

Jessen KR, Mirsky R (2005) The origin and development of glial cells in peripheral nerves. Nat Rev Neurosci 6:671-682. CrossRef Medline 
Jones GN, Tep C, Towns WH 2nd, Mihai G, Tonks ID, Kay GF, Schmalbrock PM, Stemmer-Rachamimov AO, Yoon SO, Kirschner LS (2008) Tissuespecific ablation of Prkarla causes schwannomas by suppressing neurofibromatosis protein production. Neoplasia 10:1213-1221. CrossRef Medline

Jones SE, Palmer TM (2012) Protein kinase A-mediated phosphorylation of RhoA on serine 188 triggers the rapid induction of a neuroendocrine-like phenotype in prostate cancer epithelial cells. Cell Signal 24:1504-1514. CrossRef Medline

Jung-Testas I, Schumacher M, Bugnard H, Baulieu EE (1993) Stimulation of rat Schwann cell proliferation by estradiol: synergism between the estrogen and cAMP. Brain Res Dev Brain Res 72:282-290. CrossRef Medline

Kim HA, DeClue JE, Ratner N (1997) cAMP-dependent protein kinase A is required for Schwann cell growth: interactions between the cAMP and neuregulin/tyrosine kinase pathways. J Neurosci Res 49:236-247. CrossRef Medline

Kirschner LS (2009) Use of mouse models to understand the molecular basis of tissue-specific tumorigenesis in the Carney complex. J Intern Med 266:60-68. CrossRef Medline

Kirschner LS, Carney JA, Pack SD, Taymans SE, Giatzakis C, Cho YS, ChoChung YS, Stratakis CA (2000) Mutations of the gene encoding the protein kinase A type I-alpha regulatory subunit in patients with the Carney complex. Nat Genet 26:89-92. CrossRef Medline

Kirschner LS, Kusewitt DF, Matyakhina L, Towns WH 2nd, Carney JA, Westphal H, Stratakis CA (2005) A mouse model for the Carney complex tumor syndrome develops neoplasia in cyclic AMP-responsive tissues. Cancer Res 65:4506-4514. CrossRef Medline

Krause S, Stendel C, Senderek J, Relvas JB, Suter U (2008) Small rho GTPases are key regulators of peripheral nerve biology in health and disease. J Peripher Nerv Syst 13:188-199. CrossRef Medline

Logue JS, Whiting JL, Tunquist B, Langeberg LK, Scott JD (2011) Anchored protein kinase A recruitment of active rac GTPase. J Biol Chem 286:22113-22121. CrossRef Medline

Madisen L, Zwingman TA, Sunkin SM, Oh SW, Zariwala HA, Gu H, Ng LL, Palmiter RD, Hawrylycz MJ, Jones AR, Lein ES, Zeng H (2010) A robust and high-throughput Cre reporting and characterization system for the whole mouse brain. Nat Neurosci 13:133-140. CrossRef Medline

Manchanda PK, Jones GN, Lee AA, Pringle DR, Zhang M, Yu L, La Perle KM, Kirschner LS (2013) Rac1 is required for Prkarla-mediated Nf2 suppression in Schwann cell tumors. Oncogene, in press. CrossRef Medline

Melendez-Vasquez CV, Einheber S, Salzer JL (2004) Rho kinase regulates schwann cell myelination and formation of associated axonal domains. J Neurosci 24:3953-3963. CrossRef Medline

Monje PV, Bartlett Bunge M, Wood PM (2006) Cyclic AMP synergistically enhances neuregulin-dependent ERK and akt activation and cell cycle progression in Schwann cells. Glia 53:649-659. CrossRef Medline

Monk KR, Naylor SG, Glenn TD, Mercurio S, Perlin JR, Dominguez C, Moens CB, Talbot WS (2009) A G-protein-coupled receptor is essential for Schwann cells to initiate myelination. Science 325:1402-1405. CrossRef Medline

Monk KR, Oshima K, Jörs S, Heller S, Talbot WS (2011) Gpr126 is essential for peripheral nerve development and myelination in mammals. Development 138:2673-2680. CrossRef Medline

Monuki ES, Weinmaster G, Kuhn R, Lemke G (1989) SCIP: a glial POU domain gene regulated by cyclic AMP. Neuron 3:783-793. CrossRef Medline

Morgan L, Jessen KR, Mirsky R (1991) The effects of cAMP on differentia- tion of cultured Schwann cells: progression from an early phenotype $(04+)$ to a myelin phenotype (P0+, GFAP-, N-CAM-, NGFreceptor-) depends on growth inhibition. J Cell Biol 112:457-467. CrossRef Medline

Pereira JA, Lebrun-Julien F, Suter U (2012) Molecular mechanisms regulating myelination in the peripheral nervous system. Trends Neurosci 35: 123-134. CrossRef Medline

Qiao J, Holian O, Lee BS, Huang F, Zhang J, Lum H (2008) Phosphorylation of GTP dissociation inhibitor by PKA negatively regulates RhoA. Am J Physiol Cell Physiol 295:C1161-C1168. CrossRef Medline

Ryu EJ, Wang JY, Le N, Baloh RH, Gustin JA, Schmidt RE, Milbrandt J (2007) Misexpression of Pou3f1 results in peripheral nerve hypomyelination and axonal loss. J Neurosci 27:11552-11559. CrossRef Medline

Skalhegg BS, Tasken K (2000) Specificity in the cAMP/PKA signaling pathway: differential expression, regulation, and subcellular localization of subunits of PKA. Front Biosci 5:D678-D6793. CrossRef Medline

Sobue G, Shuman S, Pleasure D (1986) Schwann cell responses to cyclic AMP: proliferation, change in shape, and appearance of surface galactocerebroside. Brain Res 362:23-32. CrossRef Medline

Stergiopoulos SG, Stratakis CA (2003) Human tumors associated with Carney complex and germline PRKAR1A mutations: a protein kinase A disease! FEBS Lett 546:59-64. CrossRef Medline

Stewart HJ, Eccleston PA, Jessen KR, Mirsky R (1991) Interaction between cAMP elevation, identified growth factors, and serum components in regulating Schwann cell growth. J Neurosci Res 30:346-352. CrossRef Medline

Stewart HJ, Morgan L, Jessen KR, Mirsky R (1993) Changes in DNA synthesis rate in the Schwann cell lineage in vivo are correlated with the precursor: Schwann cell transition and myelination. Eur J Neurosci 5:1136-1144. CrossRef Medline

Stratakis CA (2002) Mutations of the gene encoding the protein kinase A type I-alpha regulatory subunit (PRKAR1A) in patients with the "complex of spotty skin pigmentation, myxomas, endocrine overactivity, and schwannomas" (Carney complex). Ann N Y Acad Sci 968:3-21. CrossRef Medline

Taylor SS, Kim C, Vigil D, Haste NM, Yang J, Wu J, Anand GS (2005) Dynamics of signaling by PKA. Biochim Biophys Acta 1754:25-37. CrossRef Medline

Williams JP, Wu J, Johansson G, Rizvi TA, Miller SC, Geiger H, Malik P, Li W, Mukouyama YS, Cancelas JA, Ratner N (2008) Nf1 mutation expands an EGFR-dependent peripheral nerve progenitor that confers neurofibroma tumorigenic potential. Cell Stem Cell 3:658-669. CrossRef Medline

Woodhoo A, Sommer L (2008) Development of the Schwann cell lineage: from the neural crest to the myelinated nerve. Glia 56:1481-1490. CrossRef Medline

Wu J, Williams JP, Rizvi TA, Kordich JJ, Witte D, Meijer D, StemmerRachamimov AO, Cancelas JA, Ratner N (2008) Plexiform and dermal neurofibromas and pigmentation are caused by Nf1 loss in desert hedgehog-expressing cells. Cancer Cell 13:105-116. CrossRef Medline

Yin Z, Jones GN, Towns WH 2nd, Zhang X, Abel ED, Binkley PF, Jarjoura D, Kirschner LS (2008) Heart-specific ablation of Prkarla causes failure of heart development and myxomagenesis. Circulation 117:1414-1422. CrossRef Medline

Yoon C, Korade Z, Carter BD (2008) Protein kinase A-induced phosphorylation of the p65 subunit of nuclear factor-kappaB promotes Schwann cell differentiation into a myelinating phenotype. J Neurosci 28:37383746. CrossRef Medline 